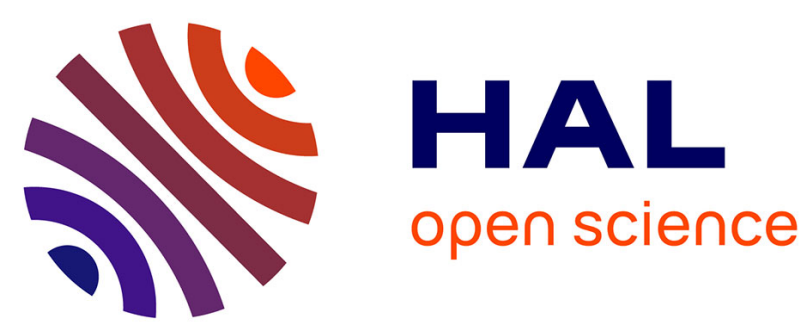

\title{
Cleaved High Molecular Weight Kininogen, a Novel Factor in the Regulation of Matrix Metalloproteinases in Vascular Smooth Muscle Cells
}

\author{
Uwe Vosgerau, Diljara Lauer, Thomas Unger, Elena Kaschina
}

\section{- To cite this version:}

Uwe Vosgerau, Diljara Lauer, Thomas Unger, Elena Kaschina. Cleaved High Molecular Weight Kininogen, a Novel Factor in the Regulation of Matrix Metalloproteinases in Vascular Smooth Muscle Cells. Biochemical Pharmacology, 2009, 79 (2), pp.172. 10.1016/j.bcp.2009.08.004 . hal-00535823

HAL Id: hal-00535823

https://hal.science/hal-00535823

Submitted on 13 Nov 2010

HAL is a multi-disciplinary open access archive for the deposit and dissemination of scientific research documents, whether they are published or not. The documents may come from teaching and research institutions in France or abroad, or from public or private research centers.
L'archive ouverte pluridisciplinaire HAL, est destinée au dépôt et à la diffusion de documents scientifiques de niveau recherche, publiés ou non, émanant des établissements d'enseignement et de recherche français ou étrangers, des laboratoires publics ou privés. 


\section{Accepted Manuscript}

Title: Cleaved High Molecular Weight Kininogen, a Novel Factor in the Regulation of Matrix Metalloproteinases in Vascular Smooth Muscle Cells

Authors: Uwe Vosgerau, Diljara Lauer, Thomas Unger, Elena Kaschina

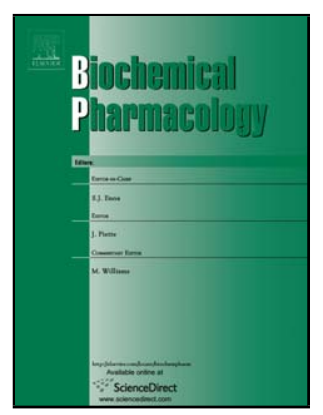

PII: S0006-2952(09)00683-2

DOI: doi:10.1016/j.bcp.2009.08.004

Reference: BCP 10287

To appear in: $\quad B C P$

Received date: $\quad$ 19-5-2009

Revised date: $\quad 3-8-2009$

Accepted date: $\quad$ 5-8-2009

Please cite this article as: Vosgerau U, Lauer D, Unger T, Kaschina E, Cleaved High Molecular Weight Kininogen, a Novel Factor in the Regulation of Matrix Metalloproteinases in Vascular Smooth Muscle Cells, Biochemical Pharmacology (2008), doi:10.1016/j.bcp.2009.08.004

This is a PDF file of an unedited manuscript that has been accepted for publication. As a service to our customers we are providing this early version of the manuscript. The manuscript will undergo copyediting, typesetting, and review of the resulting proof before it is published in its final form. Please note that during the production process errors may be discovered which could affect the content, and all legal disclaimers that apply to the journal pertain. 
Cleaved High Molecular Weight Kininogen, a Novel Factor in the Regulation of Matrix Metalloproteinases in Vascular Smooth Muscle Cells

Uwe Vosgerau, Diljara Lauer, Thomas Unger, Elena Kaschina*

Center for Cardiovascular Research (CCR) / Institute of Pharmacology, Charité-

Universitätsmedizin Berlin, Germany

Address for correspondence:

Elena Kaschina, MD

Center for Cardiovascular Research (CCR) / Institute of Pharmacology

Charité-Universitätsmedizin Berlin

Hessische Strasse 3-4

10115 Berlin, Germany

e-mail: elena.kaschina@charite.de

PHONE: +49-30-450 525024

FAX: +49-30-450 525901 


\begin{abstract}
We previously reported that Brown Norway Katholiek rats, which feature a deficiency of plasma kininogens, develop severe abdominal aortic aneurysm. Increased activity of matrix metalloproteinases (MMPs) in the aortic wall, leading to degradation of extracellular matrix components, is considered to play a crucial role in aneurysm formation. Using an in vitro model of vascular smooth muscle cells (VSMCs), cultured from the rat aorta, we investigated whether the cleaved form of high molecular weight kininogen, designated HKa, affects the expression of MMP-9 and MMP-2 and their tissue inhibitors (TIMPs). Treatment of VSMCs with HKa reduced in a concentration-dependent manner IL- $1 \alpha$-induced release of MMP-9 and MMP-2, associated with decreased MMP enzymatic activity levels in conditioned media, as demonstrated by gelatin zymography and fluorescein-labeled gelatin substrate assay, respectively. Real-time PCR revealed that HKa reduced corresponding MMP-9 mRNA levels. Further investigations showed that this effect did not result from a modified rate of MMP-9 mRNA degradation. TIMP-1 mRNA levels, already increased as a result of cytokinestimulation, were significantly enhanced by HKa. Furthermore, we found elevated basal mRNA expression levels of MMP-2 and TIMP-2 in VSMCs derived from kininogen-deficient Brown Norway Katholiek rats. These results demonstrate for the first time that HKa affects the regulation of MMPs in VSMCs.
\end{abstract}

Key words: kininogen $\cdot$ matrix metalloproteinases $\cdot$ tissue inhibitors of MMPs $\cdot$ smooth muscle cells - vascular biology 


\section{Introduction}

The vascular extracellular matrix (ECM) is a complex network of proteins and proteoglycans which exists in a state of constant turnover. An intricate balance between synthesis and degradation of its components controls the homeostasis within the ECM. Matrix metalloproteinases (MMPs) are a family of endopeptidases with proteolytic activity towards a variety of ECM components such as collagens and elastin. In normal physiological vascular remodeling the activity of MMPs is tightly regulated to prevent the ECM from excessive degradation. Vascular smooth muscle cells (VSMCs) are the most abundant cell type in the aortic wall and a major source of ECM proteins. Furthermore, VSMCs produce and release MMPs as well as the endogenous tissue inhibitors of MMPs, the TIMPs [1].

Excessive degradation of the ECM, leading to weakening and dilatation of the aortic wall, is a hallmark in the pathogenesis of aortic aneurysm. Increased activity of MMPs in the aortic wall has been extensively demonstrated in established and expanding aneurysm $[2,3,4]$. Thereby, a pivotal role has been attributed to MMP-2 and MMP-9 in the process of aneurysm development. MMP-2 has been identified as the principal matrix metalloproteinase in small aneurysm, whereas an increasing activity of MMP-9 was found in large aneurysm [5]. Longo et al [6] suggest that MMP-2 and MMP-9 are both required and work in concert to produce abdominal aortic aneurysm.

We have previously shown that rats of the strain Brown Norway Katholiek (BN/Ka), which feature a deficiency of plasma kininogens, develop severe abdominal aortic aneurysms compared to Brown Norway (BN) rats with normal plasma kininogen levels [7]. Thereby, aneurysm formation was associated with enhanced elastolysis and increased expression of MMPs. Deficiency of kininogens in the plasma of $\mathrm{BN} / \mathrm{Ka}$ rats was attributed to a single point mutation in the kininogen gene resulting in a defective secretion of kininogens by the liver $[8]$. 
High molecular weight kininogen $(\mathrm{HK})$ is a $120 \mathrm{kDa}$ single-chain glycoprotein comprising 6 domains (designated as D1-D6) with a concentration in human plasma of $\sim 670 \mathrm{nM}$. Proteolytic cleavage of HK by kallikrein results in release of the nonapeptide bradykinin from D4. The remaining molecule is designated cleaved high molecular weight kininogen (HKa), which consists of a heavy chain and a light chain that are connected by a single disulfide bond. Conversion of $\mathrm{HK}$ to $\mathrm{HKa}$ is accompanied by a striking change in conformation as demonstrated by electron microscopy [9]. As a result of this transformation, HKa acquires new properties. HKa, but not $\mathrm{HK}$, has been demonstrated to inhibit endothelial cell proliferation which was attributed to the ability of HKa to induce apoptosis in proliferating cells [10]. Furthermore, HKa proved to be a potent inhibitor of angiogenesis in different in vivo models $[10,11]$.

In this study we investigated the effects of HKa on the expression of MMP-9 and MMP-2 as well as on TIMP-1 and TIMP-2 levels in cytokine-stimulated rat VSMCs. Furthermore, we determined basal expression levels of these MMPs and TIMPs in VSMCs derived from kininogen-deficient $\mathrm{BN} / \mathrm{Ka}$ rats. 


\section{Materials and methods}

\section{Cell isolation and culture}

Vascular smooth muscle cells were isolated from the aorta of male Wistar, $\mathrm{BN}$ and $\mathrm{BN} / \mathrm{Ka}$ rats by the explant technique, as described by Campbell et al [12] with few modifications. Briefly, under a dissecting microscope fat, connective tissue and outgoing arteries were removed from the aorta. The vessel was cut longitudinally and the endothelium was removed with a cell scraper by gentle scraping along the luminal surface. Using a scalpel, the remaining tissue was then cut into explants of 2-4 $\mathrm{mm}^{2}$. Explants were placed with the luminal side downwards in culture dishes (Primaria ${ }^{\mathrm{TM}}$, Becton Dickinson) and incubated with a minimal amount of culture medium. Isolated VSMCs were cultured in Dulbecco's modified Eagle's medium (4.5 g/L glucose) supplemented with 10\% fetal calf serum (HyClone), 2 $\mathrm{mmol} / \mathrm{L} \mathrm{L}$-glutamine and $100 \mu \mathrm{g} / \mathrm{ml}$ gentamycin in a humidified atmosphere of $5 \% \mathrm{CO}_{2}$ at $37^{\circ} \mathrm{C}$. Cells were identified by their characteristic "hill-and-valley" growth pattern and immunofluorescence staining with an anti- smooth muscle actin monoclonal antibody (Chemicon). Experiments were performed with cultures from passage 4 to 11 .

\section{Cell culture experiments}

Confluent VSMCs derived from Wistar rats were serum-deprived by incubation in low-serum medium (DMEM, supplemented with $0.2 \%$ fetal calf serum and $0.1 \%$ bovine serum albumin) for $24 \mathrm{~h}$. Cells were then incubated in fresh low-serum medium and exposed to interleukin- $1 \alpha$ (IL-1 $\alpha) 10 \mathrm{ng} / \mathrm{ml}$ (Sigma) in the presence or absence of HKa (two-chain HMW kininogen, Enzyme Research Laboratories, Swansea, UK) for $48 \mathrm{~h}$. Conditioned media were obtained by collecting the culture media at the end of the experiment. Samples were centrifuged for 10 
$\min$ at $12000 \mathrm{xg}$ to remove cellular debris and stored at $-20^{\circ} \mathrm{C}$ until use. RNA was extracted from the cell layer and processed for analysis by PCR.

\section{Gelatin zymography}

Culture media harvested from VSMCs were analysed for proteins with gelatinolytic activity by gelatin zymography. Briefly, $8 \mu 1$ (MMP-9 analysis) and $1 \mu 1$ (MMP-2 analysis) aliquots of conditioned media were resuspended in non-reducing sample buffer and applied to 8\% SDSPAGE copolymerized with gelatin $(1 \mathrm{mg} / \mathrm{ml})$. After electrophoresis, gels were washed with $2.5 \%$ Triton X-100 for $1 \mathrm{~h}$ and subsequently incubated in enzyme buffer (50 mM Tris-HCl, $\mathrm{pH}$ 7.5, $20 \mathrm{mM} \mathrm{NaCl}, 5 \mathrm{mM} \mathrm{CaCl}$, and $0.02 \%$ Brij-35) at $37^{\circ} \mathrm{C}$ overnight. The gels were then stained with $0.5 \%$ Coomassie Brilliant Blue G-250. Following destaining in 30\% methanol and $10 \%$ acetic acid, proteins having gelatinolytic activity were visualised as clear bands against a blue-stained background. Gels were scanned and densitometric analysis was performed using the image analysis program Quantity One (Biorad). Molecular sizes of bands were characterised by comparison with prestained molecular weight markers.

\section{Gelatinase/Collagenase activity assay}

Enzymatic activity of MMPs present in conditioned media was detected with the EnzChek ${ }^{\circledR}$ Gelatinase/Collagenase Assay Kit according to the directions provided by the manufacturer (Molecular Probes). Samples were incubated with $1 \mathrm{mM} p$-aminophenylmercuric acetate (APMA) for $2 \mathrm{~h}$ at $37^{\circ}$ prior to the assay, to activate proMMPs. The assay was performed with $40 \mu \mathrm{l}$ of APMA-activated conditioned media, mixed with $140 \mu 1$ reaction buffer $(50 \mathrm{mM}$ Tris- $\mathrm{HCl}, 150 \mathrm{mM} \mathrm{NaCl}, 5 \mathrm{mM} \mathrm{CaCl} 2,0.2 \mathrm{mM}$ sodium azide, $\mathrm{pH} \mathrm{7.6)} \mathrm{and} 20 \mu \mathrm{l}$ of fluorescein-labeled gelatin substrate $(0.7 \mathrm{mg} / \mathrm{ml})$, for $17 \mathrm{~h}$ at $37^{\circ} \mathrm{C}$. Fluorescence was monitored (excitation: 490/20 nm, emission: 510/10 nm) with a fluorescence plate reader 
(Victor $3^{\mathrm{TM}}$, PerkinElmer). Fluorescence intensity was corrected for background fluorescence by subtracting the value derived from a no-enzyme control (reagents without conditioned medium).

\section{Western blotting}

Cells and tissue samples were lysed in $50 \mathrm{mM}$ TrisHCl, $150 \mathrm{mM} \mathrm{NaCl}, 1 \mathrm{mM}$ EDTA, 1\% Nonidet P40, 15\% Glycerol, supplemented with protease inhibitors. Proteins were separated by $8 \%$ SDS-PAGE under reducing conditions and transferred to polyvinylidene difluoride membranes. Blots were blocked with 5\% fat-free milk and consecutively incubated with rabbit anti-kininogen antibody (sc-25799, Santa Cruz) at a dilution of 1:500 and anti-rabbit horseradish peroxidase conjugated antibody (P0217, Dako). Bands were detected by chemiluminescence using an ECL detection kit (Amersham). Detection of GAPDH on the blots by using anti-GAPDH antibody (MAB374, Chemicon) at a dilution of 1:50000 served as a loading control.

\section{Quantitative real-time PCR}

Total RNA was isolated using Trizol reagent (Invitrogen) according to the manufacturer's protocol and subsequently treated with DNase-I (Promega). One microgram RNA was reverse-transcribed using M-MLV reverse transcriptase (RNase $\mathrm{H}$ minus, Promega) in a final reaction volume of $25 \mu \mathrm{l}$. Quantitative real-time PCR was performed with the Mx3000P qPCR system (Stratagene) using SYBR Green I reaction mix and different primers (Table 1). PCR conditions comprised an initial step of $94^{\circ} \mathrm{C}(2 \mathrm{~min})$, followed by 40 cycles of $94^{\circ} \mathrm{C}(15$ $\mathrm{s}), 58^{\circ} \mathrm{C}(15 \mathrm{~s})$ and $72^{\circ} \mathrm{C}(30 \mathrm{~s})$. All samples were measured in triplicate and expression values 
were normalized to $18 \mathrm{~s}$ rRNA. Data analysis was done according to the novel GED (Gene Expressions's $\mathrm{C}_{\mathrm{T}}$ Difference) method [13].

\section{Nested PCR}

The PCRs were carried out under the same conditions as described for real-time PCR. The first PCR was performed with external HK primers (Table 1) and $1 \mu 1 \mathrm{cDNA}$ for each reaction in a final volume of $30 \mu \mathrm{l}$. For the second PCR internal HK primers were used and $10 \mu \mathrm{l}$ of a 1:100 dilution from the first amplification. Reactions performed without addition of reverse transcriptase served as negative controls (RT-). Nested PCR products were separated by electrophoresis on $2 \%$ agarose gels stained with ethidium bromide.

\section{Statistical analysis}

Data are reported as means \pm SEM calculated on the basis of at least three independent experiments. Significance was evaluated using paired Student $t$ test. A value of $p<0.05$ was considered statistically significant. 


\section{Results}

\section{Effect of HKa on cytokine-induced MMP-9 and MMP-2 secretion}

To evaluate possible effects of HKa on the secretion of MMP-9 and MMP-2, we stimulated VSMCs with IL-1 $\alpha(10 \mathrm{ng} / \mathrm{ml})$ in the presence or absence of HKa at different concentrations and performed gelatin zymography on conditioned media. As previously reported, treatment of VSMCs with cytokines such as IL-1 $\alpha$ augments protein levels of constitutively expressed MMP-2 in the cell culture media and induces de novo synthesis and secretion of MMP-9 [14]. Because the expression of both MMPs in IL-1 $\alpha$-treated VSMCs reaches a maximal level after $48 \mathrm{~h}$ of stimulation we chose incubation times of $48 \mathrm{~h}$. As shown in Fig. 1a (upper panel), gelatin zymography analysis of conditioned media from cytokine-stimulated VSMCs revealed gelatin lysis at $92 \mathrm{kDa}$ corresponding to the proform of MMP-9, as verified by conversion to the active $82-\mathrm{kDa}$ form of MMP-9 with $p$-aminophenylmercuric acetate (APMA) (Fig. 1d). As indicated by the position of molecular weight markers and the labelling at the left side, Figure 1d (lower panel) shows corresponding MMP-2 gelatinolytic bands after treatment with APMA.

Treatment of cytokine-stimulated VSMCs with HKa reduced MMP-9 release in a concentration-dependent manner. Densitometric analysis of the zymograms shows a reduction to $49 \pm 6 \%$ by $1 \mu \mathrm{M} \mathrm{HKa}$ compared with IL-1 $\alpha$ treatment alone (Fig. 1a, lower panel).

Analysis of MMP-2 levels in conditioned media by gelatin zymography (Fig. 1b, upper panel) showed that cytokine-stimulated VSMCs released more proMMP-2 $(72 \mathrm{kDa})$ into the culture media, which was paralleled by an increase of active MMP-2 levels (62 kDa). Treatment of cytokine-stimulated cells with HKa reduced proMMP-2 release with a significant reduction seen at $1 \mu \mathrm{M} \mathrm{HKa}(31 \pm 12 \%$ relative to IL-1 $\alpha$ alone $)$, paralleled by a decrease of active MMP-2 levels (26 $\pm 6 \%$ relative to IL-1 $\alpha$ alone), as shown by densitometric analysis of the 
zymograms (Fig. 1b, lower panel). Thereby, the relative ratio of active MMP-2 to proMMP-2 in the conditioned media from HKa-treated VSMCs remained almost constant (Table 2).

\section{HKa does not affect the gelatinolytic capability of released MMPs}

To evaluate whether the HKa present in cell culture media directly affects the gelatinolytic capability of the MMPs detected by gelatin zymography, we performed cell-free incubation experiments. Aliquots of conditioned media harvested from IL-1 $\alpha$ treated VSMC were incubated with or without $\mathrm{HKa}[1 \mu \mathrm{M}]$ for $48 \mathrm{~h}$ at $37^{\circ} \mathrm{C}$ and subsequently assayed by gelatin zymography. Cell-free incubation with HKa did not have an effect on gelatin lysis by proMMP-9 and the pro- and active form of MMP-2, as demonstrated by almost identical gelatinolytic bands for all samples (Fig. 1c).

\section{Effect of HKa on MMP-9 and MMP-2 mRNA levels in cytokine-stimulated VSMCs}

To evaluate whether the reduction of MMP-9 and MMP-2 release is due to a decrease of the corresponding mRNA levels, real-time PCR was performed. As shown in Fig. 2a, treatment with HKa concentration-dependently decreased the cytokine-induced MMP-9 mRNA level up to $48 \pm 5 \%$ by $1 \mu \mathrm{M}$ HKa compared with IL-1 $\alpha$ treatment alone. We next investigated whether HKa reduced the MMP-9 mRNA level by increasing the rate of mRNA degradation. VSMCs were pre-treated with IL- $1 \alpha(10 \mathrm{ng} / \mathrm{ml})$ for $48 \mathrm{~h}$ to stimulate MMP-9 mRNA expression before any further transcription was blocked by actinomycin $\mathrm{D}(5 \mu \mathrm{g} / \mathrm{ml})$. Simultaneously, cells were treated with IL-1 $\alpha(10 \mathrm{ng} / \mathrm{ml})$ in the presence or absence of HKa $[1 \mu \mathrm{M}]$ for further 12 or $24 \mathrm{~h}$. As shown in Fig. 2c, real-time PCR analysis demonstrated 
MMP-9 mRNA degradation by decreased mRNA levels after $24 \mathrm{~h}$ of actinomycin D treatment. However, an enhanced MMP-9 mRNA degradation by HKa could not be observed, indicating that its suppressive effect on mRNA levels shown in Fig. 2a is not the result of an increased rate of mRNA degradation. In contrast to the effects of IL-1 $\alpha$ and HKa on MMP-2 protein levels, real-time PCR revealed that corresponding MMP-2 mRNA levels did not vary significantly under the different treatments (Fig. 2b).

\section{Cytokine-induced increase of TIMP-1 expression is further enhanced by HKa}

We next analysed mRNA levels of TIMP-1 and TIMP-2, the endogenous inhibitors of MMPs that are expressed by VSMCs [14]. Additionally to the increase caused by cytokinestimulation, simultaneous treatment with HKa further increased TIMP-1 mRNA levels as detected by real-time PCR (Fig. 3a). This effect reached statistical significance at a HKa concentration of $1 \mu \mathrm{M}$. HKa alone had no effect on TIMP-1 mRNA expression (data not shown). TIMP-2 mRNA expression, already high under basal conditions, was affected neither by IL-1 $\alpha$ nor by HKa (Fig. 3b). Since the MMP-9/TIMP-1 ratio is considered to be an important characteristic of the pathogenesis of aneurysm we calculated MMP-9/TIMP-1 mRNA ratios which were remarkably decreased by HKa (Fig. 3c).

\section{Treatment of cytokine-stimulated VSMCs with HKa decreases MMP activity levels in} conditioned media

Concerning the effect of HKa on the expression of TIMP-1, MMP-9 and MMP-2, we investigated whether treatment of cytokine-stimulated VSMCs with HKa also results in less enzymatic MMP activity levels. Determination of total MMP activity levels were performed 
with APMA-activated conditioned media using a quenched-fluorescent gelatin substrate assay. As shown in Fig. 4, MMP activity levels were strongly increased as a result of cytokine stimulation. Significantly less MMP activity levels were detected in conditioned media of cytokine-stimulated cells treated with $100 \mathrm{nM} \mathrm{HKa}(67 \pm 6 \%)$ and $1 \mu \mathrm{M} \mathrm{HKa}(59 \pm 9 \%)$. Fluorescence intensity of samples that were not activated with APMA was only minimal above fluorescence background levels (data not shown).

\section{Elevated basal expression of MMP-2 and TIMP-2 in VSMCs derived from kininogen- deficient rats}

VSMCs isolated from the aorta of $\mathrm{BN}$ and kininogen-deficient $\mathrm{BN} / \mathrm{Ka}$ rats were grown to confluence and serum-deprived for $24 \mathrm{~h}$. Cells were further incubated in low serum medium $(0.2 \%$ FCS $)$ for $48 \mathrm{~h}$ before total RNA was extracted. Real-time PCR analysis revealed significantly elevated basal mRNA levels for MMP-2 (2.3-fold) and TIMP-2 (1.7-fold) in VSMCs derived from $\mathrm{BN} / \mathrm{Ka}$ compared to VSMCs derived from $\mathrm{BN}$ rats, whereas TIMP-1 mRNA was expressed almost to the same extent (Fig. 5). MMP-9 mRNA could not be detected under basal conditions neither in cells from $\mathrm{BN}$ nor in cells from $\mathrm{BN} / \mathrm{Ka}$ rats (data not shown).

\section{HK is not expressed by VSMCs}

To evaluate whether HK is expressed by VSMCs, analysis on mRNA and protein level was performed. We took into consideration that VSMCs might express $\mathrm{HK}$ mRNA in low abundance and hence not easily detectable by standard PCR protocols. Therefore, detection of HK mRNA was performed using a nested PCR protocol. For this purpose HK mRNA specific 
primers were designed, comprising an external and an internal primer pair. Nested PCR, including two consecutively performed PCRs with first external and then internal primer pairs, yielded the expected amplicons of $204 \mathrm{bp}$ and $101 \mathrm{bp}$, respectively, when using liver cDNA as a positive control (Fig. 6a). Nested PCR analysis of VSMCs showed no detection of HK mRNA. A total of four VSMC cultures derived from different animals were analysed. Also HK mRNA could not be detected in aortic tissue. Western blot analysis of total protein lysates confirmed the absence of HK in VSMCs (Fig. 6b). Interestingly, in contrast to mRNA analysis, Western blots showed a strong signal for HK protein in aortic tissue. 


\section{Discussion}

The pathogenesis of abdominal aortic aneurysm is characterised by a dramatic remodeling of the ECM, increased activity of MMPs and the presence of a chronic inflammatory infiltrate. In normal physiological vascular remodeling, the activity of MMPs is tightly regulated at the level of transcription, mRNA stability, posttranslational activation of proMMPs and inhibition by endogenous inhibitors.

Various inflammatory cytokines, such as IL-1 $\alpha$ and TNF- $\alpha$, are known to stimulate MMP expression by vascular cells in vitro [15]. Furthermore, several investigators have found elevated levels of inflammatory cells and cytokines in aneurysmatic tissues, including IL-1 $\alpha$ [16]. Hence, it has been hypothesized that cytokine stimulation may trigger increased production of MMPs by inflammatory and smooth muscle cells within the aortic wall [17]. Stimulation of human VSMCs with IL- $1 \alpha$ has been demonstrated to enhance release of both MMP-9 and MMP-2 into the culture media [14]. We therefore used IL-1 $\alpha$ in our cell culture experiments to evaluate possible effects of $\mathrm{HKa}$ on the expression of MMP-9 and MMP-2.

We demonstrate that HKa reduced in a concentration-dependent manner the release of MMP9 by cytokine-stimulated VSMCs. MMP-9 mRNA analysis clearly indicates, that this effect predominantly results from alterations of the corresponding mRNA levels. Since recent studies showed that cytokine-induced MMP-9 mRNA can be regulated post-transcriptionally at the level of mRNA stability $[18,19]$, we addressed the question as to whether this might be the underlying mechanism for the negative regulation of MMP-9 mRNA by HKa. Our studies using actinomycin $\mathrm{D}$, an inhibitor of eukaryotic gene transcription, demonstrated that $\mathrm{HKa}$ did not affect the rate of MMP-9 mRNA degradation, suggesting that its suppressive effect on MMP-9 mRNA levels is more likely to be the result of an inhibited MMP-9 gene transcription. 
As a result of cytokine-stimulation, VSMCs released significantly more MMP-2 into the culture media, which was diminished when cells were stimulated in the presence of HKa. Most MMPs are released as inactive pro-enzymes which require proteolytic processing to become active, a posttranslational control mechanism of MMP activity. Activation of the proMMPs in the extracellular space occurs via proteinases, including other MMPs, serine proteinases such as the plasminogen activator/plasmin system, cysteine proteinases, as well as by nonproteolytic agents such as reactive oxygen species, sulfhydryl reactive agents, and denaturants. However, MMPs that are resistant to serine proteinase activation, such as MMP2, are activated via a novel mechanism involving the MT-MMPs [20].

In our study, HKa reduced concentration-dependently levels of both active MMP-2 and proMMP-2 in conditioned media. Thereby, the relative ratio of active MMP-2 to proMMP-2 remained almost unchanged, indicating that HKa does not affect the processes that lead to conversion from pro- to active MMP-2.

To exclude the possibility that the zymographic results of MMP-levels in conditioned media might be the result of a direct interference of MMPs with $\mathrm{HKa}$, independent of cellular processes, incubations in the absence of cells were performed. We could demonstrate that 1 $\mu \mathrm{M}$ HKa did not interfere with the gelatinolytic capability of MMP-2 and MMP-9, thereby confirming that the observed effects of HKa result from a negative regulation of cellular expression. However, changes in MMP-2 release did not correspond to almost constant MMP-2 mRNA levels. This result is in line with the findings from others [14], showing that highly expressed MMP-2 mRNA under basal conditions was not affected by stimulation with various cytokines.

Concerning the potential of MMPs to degrade the ECM, their interaction with specific MMPinhibitors has to be considered. Several natural inhibitors of MMPs exist, but the most common inhibitors are TIMPs [21]. They are endogenously expressed and capable to bind 
both active MMPs and proMMPs by forming noncovalent complexes and hence inhibiting MMP activity and processing of the proMMPs, respectively. Therefore, the net proteolytic activity towards ECM components is determined by the balance between MMPs and their endogenous inhibitors. Several studies reported that the expression of both MMP-9 and TIMP-1 is highly increased in abdominal aortic aneurysms compared to normal aortas [22, 23]. Also our results show that cytokine-induced MMP-9 expression in VSMCs was paralleled by remarkably elevated TIMP-1 mRNA levels. Most interestingly, treatment with HKa further increased TIMP-1 mRNA expression. The significantly decreased ratio MMP-9 to TIMP-1 mRNA as well as the reduced enzymatic activity of MMPs in conditioned media suggests that altogether the balance between MMPs and TIMPs is shifted towards less net proteolytic activity by HKa.

Interestingly we found, by comparing VSMC cultures derived from the strains $\mathrm{BN}$ and $\mathrm{BN} / \mathrm{Ka}$, that basal mRNA levels for MMP-2 and TIMP-2 in cells derived from kininogendeficient $\mathrm{BN} / \mathrm{Ka}$ rats were significantly elevated. TIMP-2 represents a physiological inhibitor of MMP-2. However, its role regarding MMP-2 activity seems to be complex since TIMP-2 has also been demonstrated to be substantially involved in the activation of proMMP-2 at the cell surface [24]. In this context, Xiong et al [25] reported an attenuated aneurysm formation associated with less active MMP-2 levels in TIMP-2-deficient mice compared to wild-type mice. We hypothesised that VSMCs cultured from $\mathrm{BN} / \mathrm{Ka}$ rats feature a deficient $\mathrm{HK}$ expression, which might result in an increased MMP-2 and TIMP-2 expression due to the lack of inhibitory effects of HKa. To address this possibility, we first investigated whether HK is expressed by VSMCs. Since neither HK protein nor mRNA was detectable in VSMCs we can exclude any HKa effects under cell culture conditions. Interestingly, mRNA encoding HK was not detectable in aortic tissue whereas HK protein was present, thus suggesting that the detected HK is derived from blood plasma. These findings suggest that VSMCs cultured from 
$\mathrm{BN} / \mathrm{Ka}$ rats had been affected by the deficiency of plasma kininogens in vivo and that the effect is sustained in vitro under cell culture conditions. In this context, Crowther et al [26] showed an increased MMP-2 expression in aortic VSMCs cultured from aneurysmal tissue. Our results raise the question of the mechanism by which HKa exerts its effects on VSMCs. Several proteins on the surface of endothelial cells, that interact with HK or HKa, have been identified, including the urokinase plasminogen activator receptor (uPAR) [27], tropomyosin [28], globular C1q receptor [29], and cytokeratin-1 [30]. The uPAR has been found to be expressed by the VSMCs [31]. This receptor, as a part of plasminogen activator/plasmin system mediates the generation of proteolytic activity and subsequently contributes to ECM degradation. Therefore, uPAR may be a possible candidate for HKa binding in the VSMCs. However, until know a specific receptor for HKa on VSMCs has not been identified and the underlying mechanism(s) for its effects demonstrated in this study remains to be evaluated. In summary, our results show for the first time that HKa affects the regulation of MMPs in VSMCs as demonstrated by a negative regulation of cytokine-induced MMP expression and activity. Furthermore, the finding that VSMCs from kininogen-deficient $\mathrm{BN} / \mathrm{Ka}$ rats feature elevated basal MMP-2 and TIMP-2 expression levels indicates that HKa plays a role in the regulation of MMPs. This study suggests that $\mathrm{HKa}$ might contribute to prevent the extracellular matrix from excessive degradation in the context of physiological and pathophysiological vascular remodeling.

\section{Acknowledgements}

This study was supported by a grant from German Ministry of Education and Research (BMBF) within the Competence Network of National Genomic Research (NGFN-2) for cardiovascular diseases. 


\section{References}

1. Fabunmi RP, Baker AH, Murray EJ, Booth RF, Newby AC.(1996) Divergent regulation by growth factors and cytokines of $95 \mathrm{kDa}$ and $72 \mathrm{kDa}$ gelatinases and tissue inhibitors or metalloproteinases- $1,-2$, and -3 in rabbit aortic smooth muscle cells. Biochem J;315 ( Pt 1):335-342.

2. McMillan WD, Patterson BK, Keen RR, Pearce WH. In situ localization and quantification of seventy-two-kilodalton type IV collagenase in aneurysmal, occlusive, and normal aorta. J Vasc Surg 1995;22:295-305.

3. Davis V, Persidskaia R, Baca-Regen L, Itoh Y, Nagase H, Persidsky Y, Ghorpade A, et al. (1998) Matrix metalloproteinase-2 production and its binding to the matrix are increased in abdominal aortic aneurysms. Arterioscler Thromb Vasc Biol;18:16251633.

4. Kadoglou NP, Liapis CD (2004) Matrix metalloproteinases: contribution to pathogenesis,diagnosis, surveillance and treatment of abdominal aortic aneurysms. Curr Med Res Opin.20:419-432

5. Freestone T, Turner RJ, Coady A, Higman DJ, Greenhalgh RM, Powell JT (1995) Inflammation and matrix metalloproteinases in the enlarging abdominal aortic aneurysm. Arterioscler Thromb Vasc Biol. 15:1145-1151

6. Longo GM, Xiong W, Greiner TC, Zhao Y, Fiotti N, Baxter BT (2002) Matrix metalloproteinases 2 and 9 work in concert to produce aortic aneurysms. J Clin Invest. 110:625-632

7. Kaschina E, Stoll M, Sommerfeld M, Steckelings UM, Kreutz R, Unger T (2004) Genetic kininogen deficiency contributes to aortic aneurysm formation but not to atherosclerosis. Physiol Genomics. 19:41-49

8. Hayashi I, Oh-ishi S (1993) Plasma kininogen deficiency: associated defective secretion of kininogens by primary cultures of hepatocytes from brown Norway Katholiek rats. J Biochem. 113:531-537

9. Weisel JW, Nagaswami C, Woodhead JL, DeLa Cadena RA, Page JD, Colman RW (1994) The shape of high molecular weight kininogen. Organization into structural domains, changes with activation, and interactions with prekallikrein, as determined by electron microscopy. J Biol Chem. 269:10100-10106

10. Zhang JC, Claffey K, Sakthivel R, Darzynkiewicz Z, Shaw DE, Leal J, Wang YC, Lu FM, McCrae KR (2000) Two-chain high molecular weight kininogen induces endothelial cell apoptosis and inhibits angiogenesis: partial activity within domain 5 . Faseb J. 14:2589-2600 
11. Colman RW, Jameson BA, Lin Y, Johnson D, Mousa SA (2000) Domain 5 of high molecular weight kininogen (kininostatin) down-regulates endothelial cell proliferation and migration and inhibits angiogenesis. Blood. 95:543-550

12. Campbell JH, Campbell GR (1993) Culture techniques and their applications to studies of vascular smooth muscle. Clin Sci (Lond). 85:501-513

13. Schefe JH, Lehmann KE, Buschmann IR, Unger T, Funke-Kaiser H (2006) Quantitative real-time RT-PCR data analysis: current concepts and the novel "gene expression's CT difference" formula. J Mol Med. 84:901-910

14. Galis ZS, Muszynski M, Sukhova GK, Simon-Morrissey E, Unemori EN, Lark MW, Amento E, Libby P (1994) Cytokine-stimulated human vascular smooth muscle cells synthesize a complement of enzymes required for extracellular matrix digestion. Circ Res. 75:181-189

15. Chase AJ, Newby AC (2003) Regulation of matrix metalloproteinase (matrixin) genes in blood vessels: a multi-step recruitment model for pathological remodelling. J Vasc Res. 40:329-343

16. Middleton RK, Lloyd GM, Bown MJ, Cooper NJ, London NJ, Sayers RD (2007) The pro-inflammatory and chemotactic cytokine microenviroment of the abdominal aortic aneurysm wall: a protein array study. J Vasc Surg 25:574-580

17. McMillan WD, Pearce WH (1997b) Inflammation and cytokine signaling in aneurysms. Ann Vasc Surg. 11:540-545

18. Eberhardt W, Akool el S, Rebhan J, Frank S, Beck KF, Franzen R, Hamada FM, Pfeilschifter J (2002) Inhibition of cytokine-induced matrix metalloproteinase 9 expression by peroxisome proliferator-activated receptor alpha agonists is indirect and due to a NO-mediated reduction of mRNA stability. J Biol Chem. 277:33518-33528

19. Akool el S, Kleinert H, Hamada FM, Abdelwahab MH, Forstermann U, Pfeilschifter J, Eberhardt W (2003) Nitric oxide increases the decay of matrix metalloproteinase 9 mRNA by inhibiting the expression of mRNA-stabilizing factor HuR. Mol Cell Biol. 23:4901-4916

20. Curry TE, Jr., Osteen KG. (2003) The matrix metalloproteinase system: changes, regulation, and impact throughout the ovarian and uterine reproductive cycle. Endocr Rev 24:428-465

21. Klein G, Vellenga E, Fraaije MW, Kamps WA, de Bont ESJM (2004) The possible role of matrix metalloproteinase (MMP)-2 and MMP-9 in cancer, e.g. acute leukaemia. Critical Reviews in Onkology/Hematology 50: 87-100 
22. Tamarina NA, McMillan WD, Shively VP, Pearce WH (1997) Expression of matrix metalloproteinases and their inhibitors in aneurysms and normal aorta. Surgery. 122:264-271; discussion 271-262

23. Thompson RW, Holmes DR, Mertens RA, Liao S, Botney MD, Mecham RP, Welgus HG, Parks WC (1995) Production and localization of 92-kilodalton gelatinase in abdominal aortic aneurysms. An elastolytic metalloproteinase expressed by aneurysminfiltrating macrophages. J Clin Invest. 96:318-326

24. Butler GS, Butler MJ, Atkinson SJ, Will H, Tamura T, Schade van Westrum S, Crabbe T, Clements J, d'Ortho MP, Murphy G (1998) The TIMP2 membrane type 1 metalloproteinase "receptor" regulates the concentration and efficient activation of progelatinase A. A kinetic study. J Biol Chem. 273:871-880

25. Xiong W, Knispel R, Mactaggart J, Baxter BT (2006) Effects of tissue inhibitor of metalloproteinase 2 deficiency on aneurysm formation. J Vasc Surg. 44:1061-1066

26. Crowther M, Goodall S, Jones JL, Bell PR, Thompson MM (2000) Increased matrix metalloproteinase 2 expression in vascular smooth muscle cells cultured from abdominal aortic aneurysms. J Vasc Surg. 32:575-583

27. Cao DJ, Guo YL, Colman RW (2004) Urokinase-type plasminogen activator receptor is involved in mediating the apoptotic effect of cleaved high molecular weight kininogen in human endothelial cells. Circ Res. 94:1227-1234

28. Zhang JC, Donate F, Qi X, Ziats NP, Juarez JC, Mazar AP, Pang YP, McCrae KR (2002) The antiangiogenic activity of cleaved high molecular weight kininogen is mediated through binding to endothelial cell tropomyosin. Proc Natl Acad Sci U S A. 99:12224-12229

29. Herwald H, Dedio J, Kellner R, Loos M, Muller-Esterl W (1996) Isolation and characterization of the kininogen-binding protein $\mathrm{p} 33$ from endothelial cells. Identity with the gC1q receptor. J Biol Chem. 271:13040-13047

30. Hasan AA, Zisman T, Schmaier AH (1998) Identification of cytokeratin 1 as a binding protein and presentation receptor for kininogens on endothelial cells. Proc Natl Acad Sci U S A. 95:3615-362

31. Dumler I, Weis A, Mayboroda OA, Maasch C, Jerke U, Haller H, Gulba DC (1998) The Jak/Stat pathway and urokinase receptor signaling in human aortic vascular smooth muscle cells. J Biol Chem. 273:315-321 


\section{Figure Legends}

Fig. 1 Effect of HKa on cytokine-induced MMP-9 and MMP-2 secretion. VSMCs were kept under basal conditions (control) (-) or treated simultaneously with $10 \mathrm{ng} / \mathrm{ml} \mathrm{IL-1 \alpha (+)}$ and $\mathrm{HKa}$ at the indicated concentrations for $48 \mathrm{~h}$. Gelatin zymography with aliquots of conditioned media revealed gelatinolytic bands corresponding to proMMP-9 (a), proMMP-2 and active MMP-2 (b). The position of prestained molecular weight markers is indicated in kilodaltons. Bars represent densitometric data (mean \pm SEM) of four independent experiments. In every experiment, values of gelatin lysis were normalised to the corresponding bands in conditioned media of VSMCs kept under basal conditions (MMP-2 analysis) or treated with IL-1 $\alpha$ only (MMP-9 analysis). c Cell-free incubation with HKa. Aliquots of conditioned media from VSMCs stimulated for $48 \mathrm{~h}$ with IL- $1 \alpha$ were mixed with $\mathrm{HKa}[1 \mu \mathrm{M}]$. Samples were incubated for $48 \mathrm{~h}$ at $37^{\circ} \mathrm{C}$ and subsequently assayed by gelatin zymography. Results are shown as triplicates. d Conversion of proMMP-9 to active MMP-9 by treatment with $p$-aminophenylmercuric acetate (APMA). Conditioned media from IL-1 $\alpha$ stimulated VSMCs were incubated for $3 \mathrm{~h}$ at $37^{\circ} \mathrm{C}$ with APMA $[1.0 \mathrm{mM}]$ before being subjected to gelatin zymography. $* \mathrm{p}<0.05, * * \mathrm{p}<0.01$

Fig. 2 Real-time PCR analysis of MMP-9 (a) and MMP-2 (b) mRNA levels in untreated VSMCs (-) or VSMCs treated for $48 \mathrm{~h}$ with $10 \mathrm{ng} / \mathrm{ml} \mathrm{IL-1 \alpha (+)}$ in the presence or absence of $\mathrm{HKa}$ at different concentrations. Bars represent expression ratios (mean $\pm \mathrm{SEM}$ ), normalised to 18 s rRNA, relative to IL-1 $\alpha$ treatment alone (MMP-9) or control (MMP-2). c Effect of HKa on MMP-9 mRNA degradation. VSMCs were pre-treated for $48 \mathrm{~h}$ with IL-1 $\alpha(10 \mathrm{ng} / \mathrm{ml})$ and subsequently incubated with actinomycin D (5 $\mu \mathrm{g} / \mathrm{ml})$ and IL-1 $\alpha(10 \mathrm{ng} / \mathrm{ml})$ in the absence or presence of HKa $[1 \mu \mathrm{M}]$ for additional 12 or $24 \mathrm{~h}$. Results from real-time PCR 
analysis are expressed as percentage (mean \pm SEM) relative to MMP-9 mRNA levels before addition of actinomycin D. ${ }^{*} \mathrm{p}<0.05, * * \mathrm{p}<0.01$

Fig. 3 Effect of HKa on TIMP-1 and TIMP-2 mRNA levels in cytokine-stimulated VSMCs. VSMCs were kept under basal conditions (control) (-) or treated simultaneously with IL-1 $\alpha$ $10 \mathrm{ng} / \mathrm{ml}(+)$ and HKa at the indicated concentrations for $48 \mathrm{~h}$. TIMP-1 (a) and TIMP-2 (b) mRNA levels were analysed by real-time PCR. Bars represent expression ratios (mean \pm SEM), normalised to $18 \mathrm{~s}$ rRNA, relative to control. c MMP-9/TIMP-1 mRNA ratios were calculated for each experiment using the corresponding expression values normalised to $18 \mathrm{~s}$ rRNA. Bars represent the means \pm SEM relative to cells treated with IL-1 $\alpha$ only.

$* \mathrm{p}<0.05, * * * \mathrm{p}<0.001$

Fig. 4 Assay of enzymatic activity in conditioned culture media using fluorescein-labeled gelatin. Conditioned media from VSMCs kept under basal conditions (control) (-) or treated simultaneously with IL-1 $\alpha 10 \mathrm{ng} / \mathrm{ml}(+)$ and $\mathrm{HKa}$ at the indicated concentrations for $48 \mathrm{~h}$ were analysed for enzymatic MMP activity. Samples were activated with APMA for $2 \mathrm{~h}$ and subsequently subjected to a quenched-fluorescent gelatin substrate assay. Fluorescence intensity measured in samples from VSMCs stimulated with IL-1 $\alpha$ only was set as $100 \%$.

$* \mathrm{p}<0.05, * * \mathrm{p}<0.01$

Fig. 5 mRNA levels under basal conditions. VSMCs derived from rats of the strains BN and $\mathrm{BN} / \mathrm{Ka}$ were cultured under basal conditions and mRNA levels were determined by real-time PCR. Results (means $\pm \mathrm{SD}$ ) are shown as percent of basal mRNA expression in VSMCs from $\mathrm{BN}$ rats. $* \mathrm{p}<0.05, * * * \mathrm{p}<0.001$

Fig. 6 Expression of HK mRNA and protein in rat liver, aorta and VSMCs. a Nested PCR analysis of HK mRNA expression showing products from two consecutively performed PCRs 
using an external and an internal primer pair, respectively. 18s rRNA was amplified simultaneously as an internal control. L: 100 bp DNA ladder, RT+: PCR as described in methods, RT-: negative control without addition of reverse transcriptase. b Western blot analysis of total protein lysates showing detection of HK heavy chain $(62 \mathrm{kD})$. Detection of GAPDH on the same blot was performed as a loading control 
Table 1 Sequences of primers used for real-time PCR and nested PCR

(For: Forward, Rev: Reverse).

\begin{tabular}{|c|c|c|c|}
\hline Gene & $\begin{array}{l}\text { Accesion } \\
\text { Number }\end{array}$ & Primer Sequences 5'-3' & $\begin{array}{l}\text { Amplicon } \\
\text { Length [bp] }\end{array}$ \\
\hline MMP-2 & NM_031054.1 & $\begin{array}{l}\text { For: GACGCTGGGAGCATGGAG } \\
\text { Rev: TTACGCGGACCACTTGTCC }\end{array}$ & 1 \\
\hline MMP-9 & NM_031055 & $\begin{array}{l}\text { For: CTTCTCTGGGCGCAAAATG } \\
\text { Rev: CCGGTGACCAGGGTTACCT }\end{array}$ & 102 \\
\hline TIMP-1 & NM_053819.1 & $\begin{array}{l}\text { For: GTGCACAGTGTTTCCCTGTT } \\
\text { Rev: CTGGTAGCCCTTCTCAGAGC }\end{array}$ & 103 \\
\hline TIMP-2 & NM_021989.2 & $\begin{array}{l}\text { For: CGAATTTATCTACACGGCCCC } \\
\text { Rev: CCGCCTTCCCTGCAATTAG }\end{array}$ & 92 \\
\hline HK external & NM_012741 & $\begin{array}{l}\text { For: CTTGAACCCTCCCCTAGCTC } \\
\text { Rev: CCAGGACACTTGTGGGAAGT }\end{array}$ & 204 \\
\hline HK internal & NM_012741 & $\begin{array}{l}\text { For: TATGACACGGAGACCCATGA } \\
\text { Rev: TGGGAAGTTGCTTCTGGAAA }\end{array}$ & 101 \\
\hline $18 \mathrm{~s}$ rRNA & X01117.1 & $\begin{array}{l}\text { For: CCGCAGCTAGGAATAATGGAATA } \\
\text { Rev: TCTAGCGGCGCAATACGAAT }\end{array}$ & 108 \\
\hline
\end{tabular}


Table 2 The relative ratio of active MMP-2 to proMMP-2

\begin{tabular}{lc}
\hline Treatment Group & OD aMMP-2/OD proMMP-2 \\
\hline Control & $4.97( \pm 0.89)$ \\
IL-1 $\alpha[10 \mathrm{ng} / \mathrm{ml}]$ & $3.87( \pm 0.72)^{*}$ \\
$+\mathrm{HKa}[10 \mathrm{nM}]$ & $3.85( \pm 0.60)^{\#}$ \\
$+\mathrm{HKa}[100 \mathrm{nM}]$ & $4.10( \pm 0.74)^{\#}$ \\
$+\mathrm{HKa}[1 \mu \mathrm{M}]$ & $4.09( \pm 0.75)^{\#}$ \\
\hline
\end{tabular}

The relative ratio of active MMP-2 to proMMP-2 in the conditioned media was determined for each experiment using the values for optical density (OD) of the corresponding gelatinolytic bands obtained from densitometric analysis of the zymograms. Values represent the mean $( \pm$ SEM).

* not significant vs control group

\# not significant vs IL-1 $\alpha$ group 
a

proMMP-9

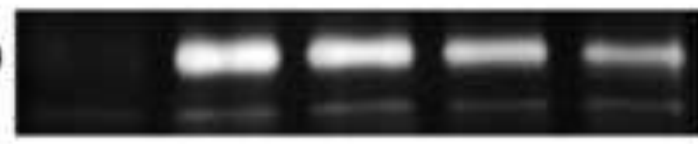

$-95 \mathrm{kD}$

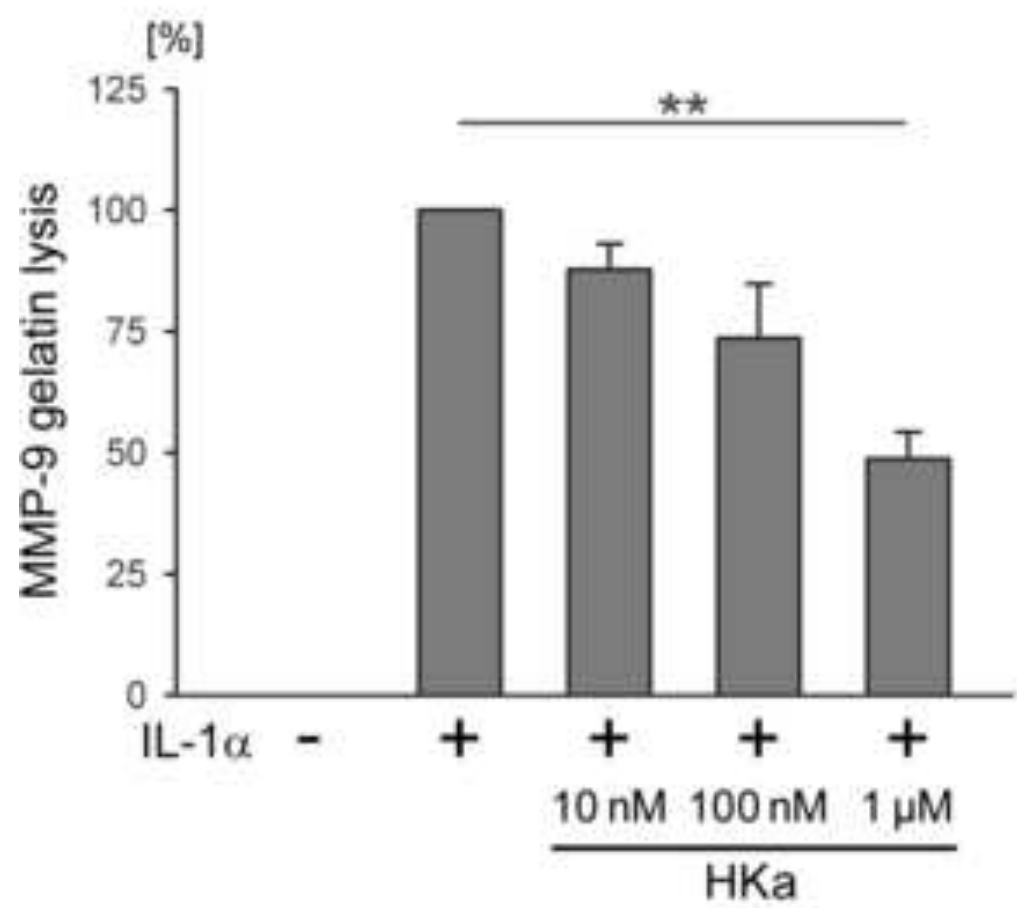

b
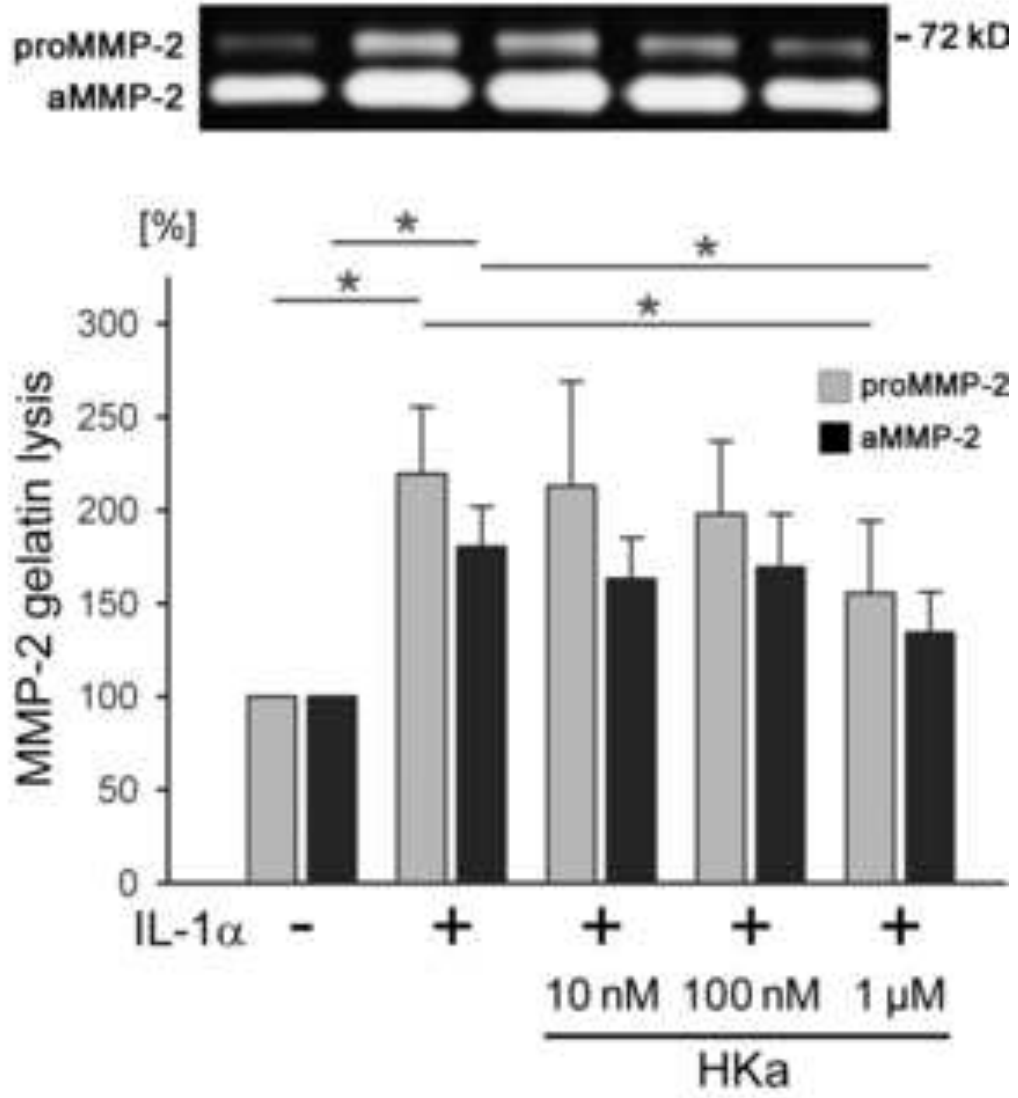

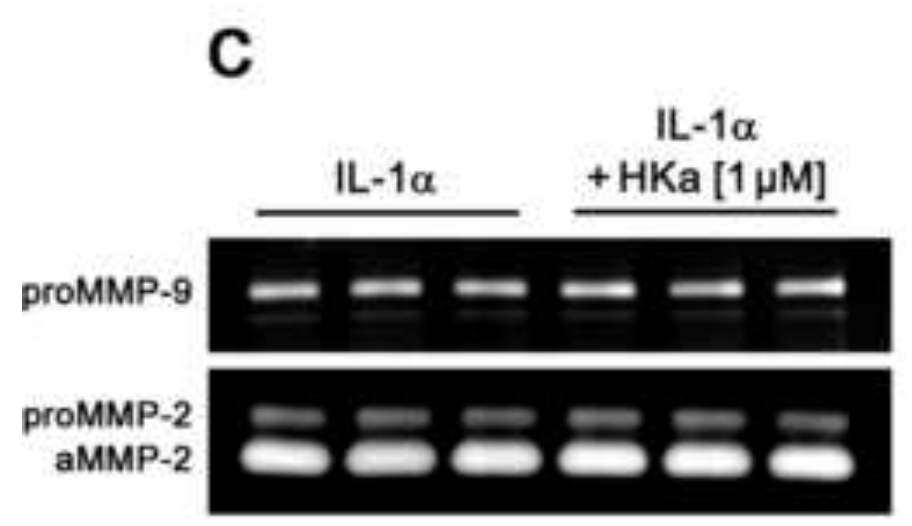

d

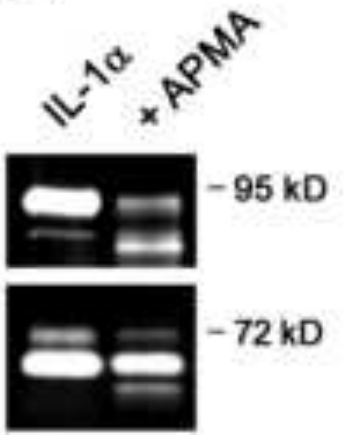



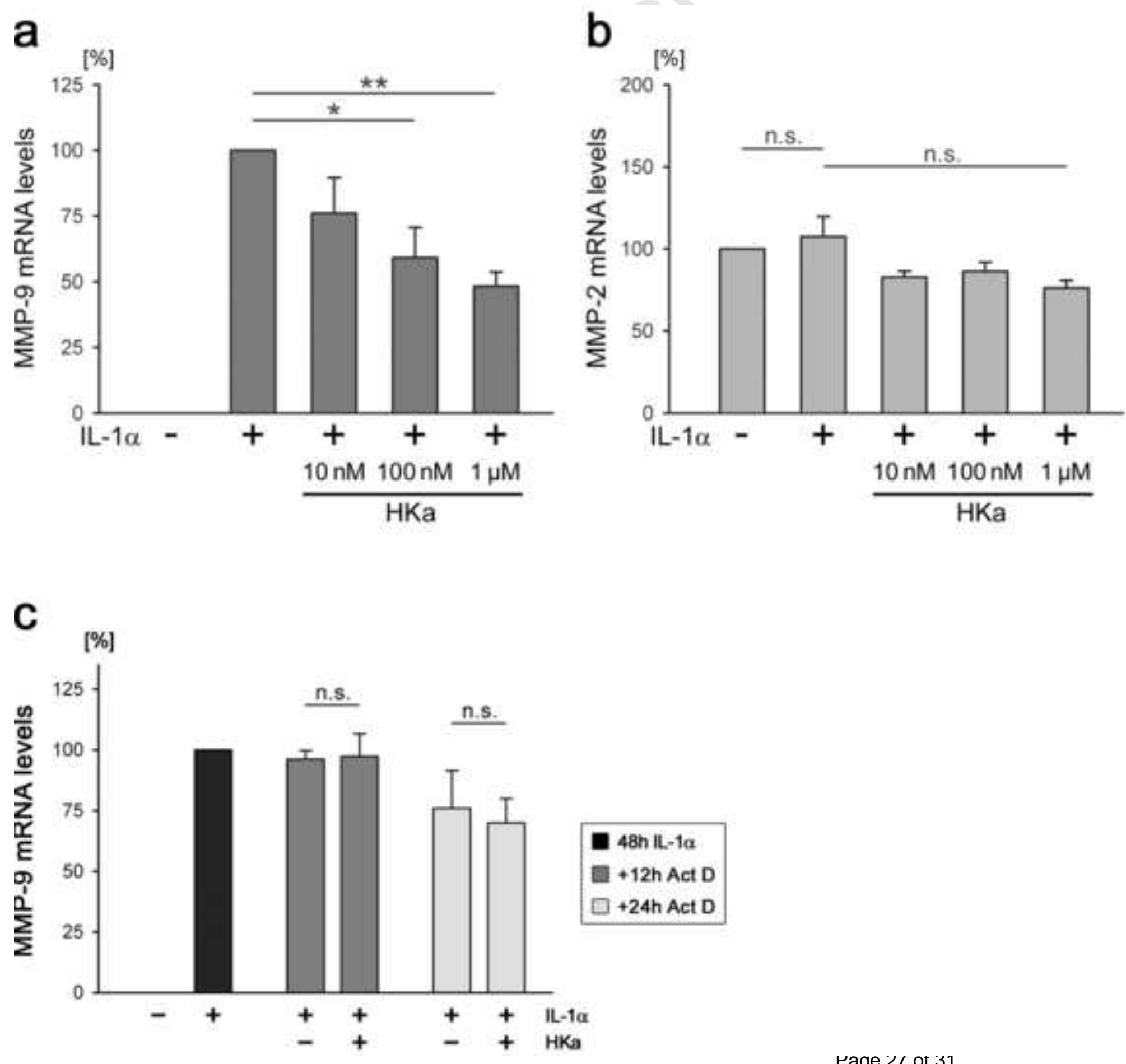
a

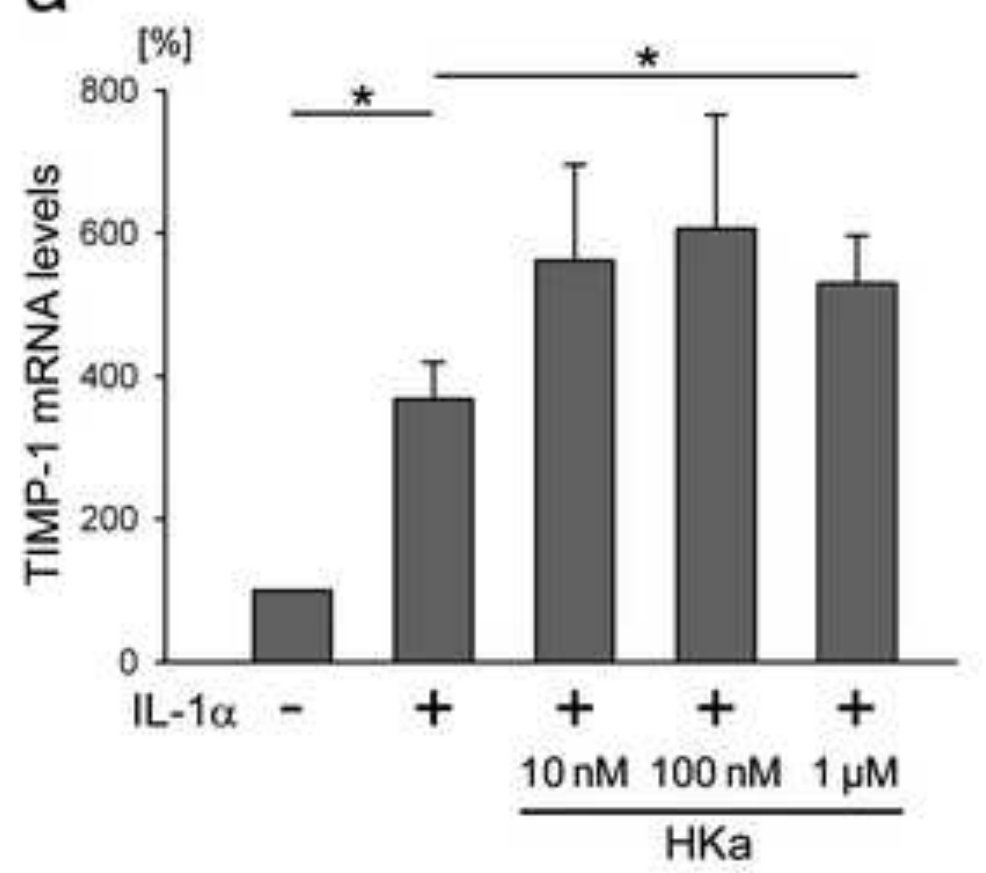

C

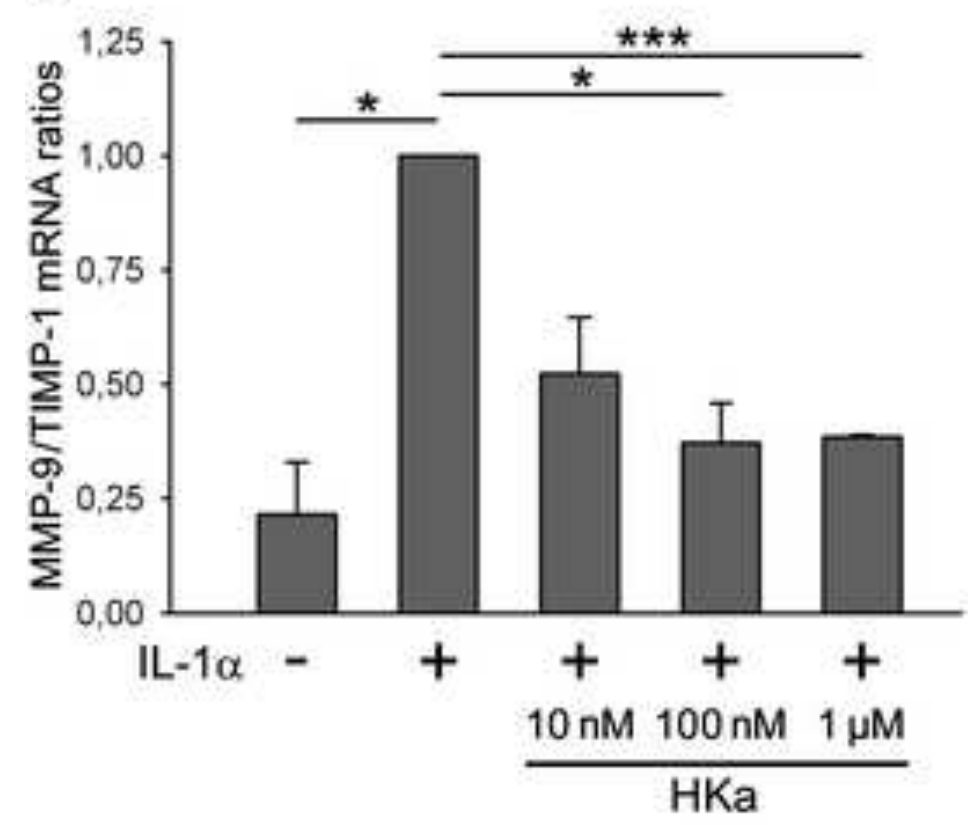

b

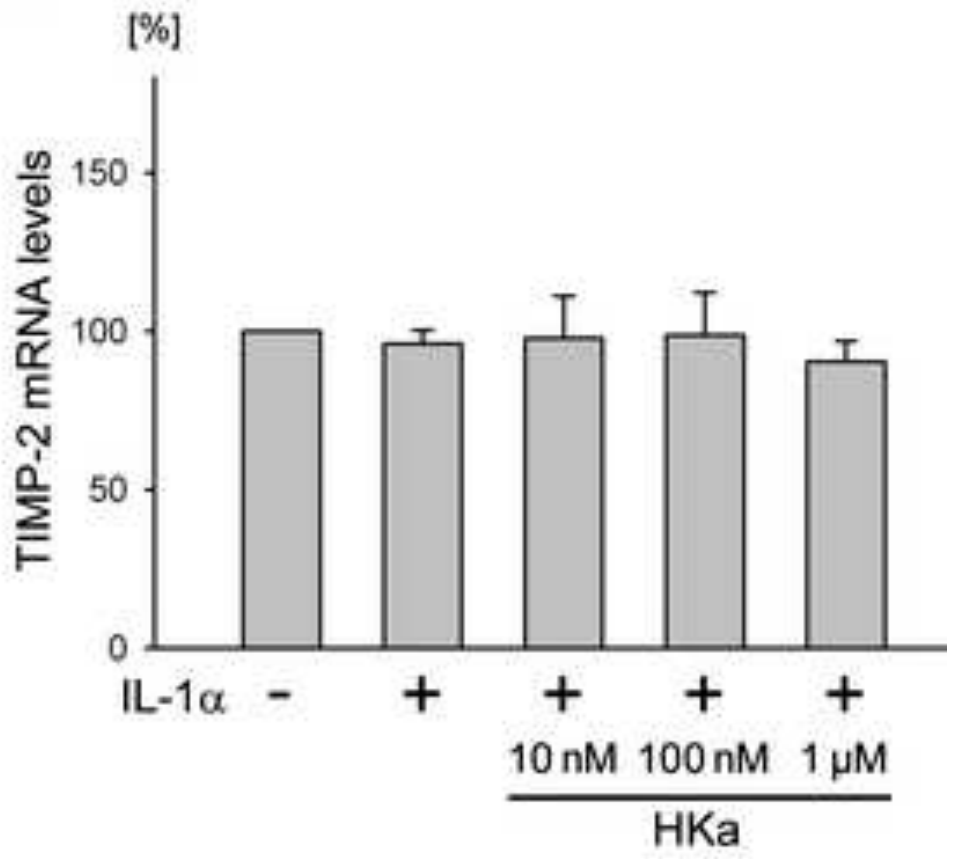




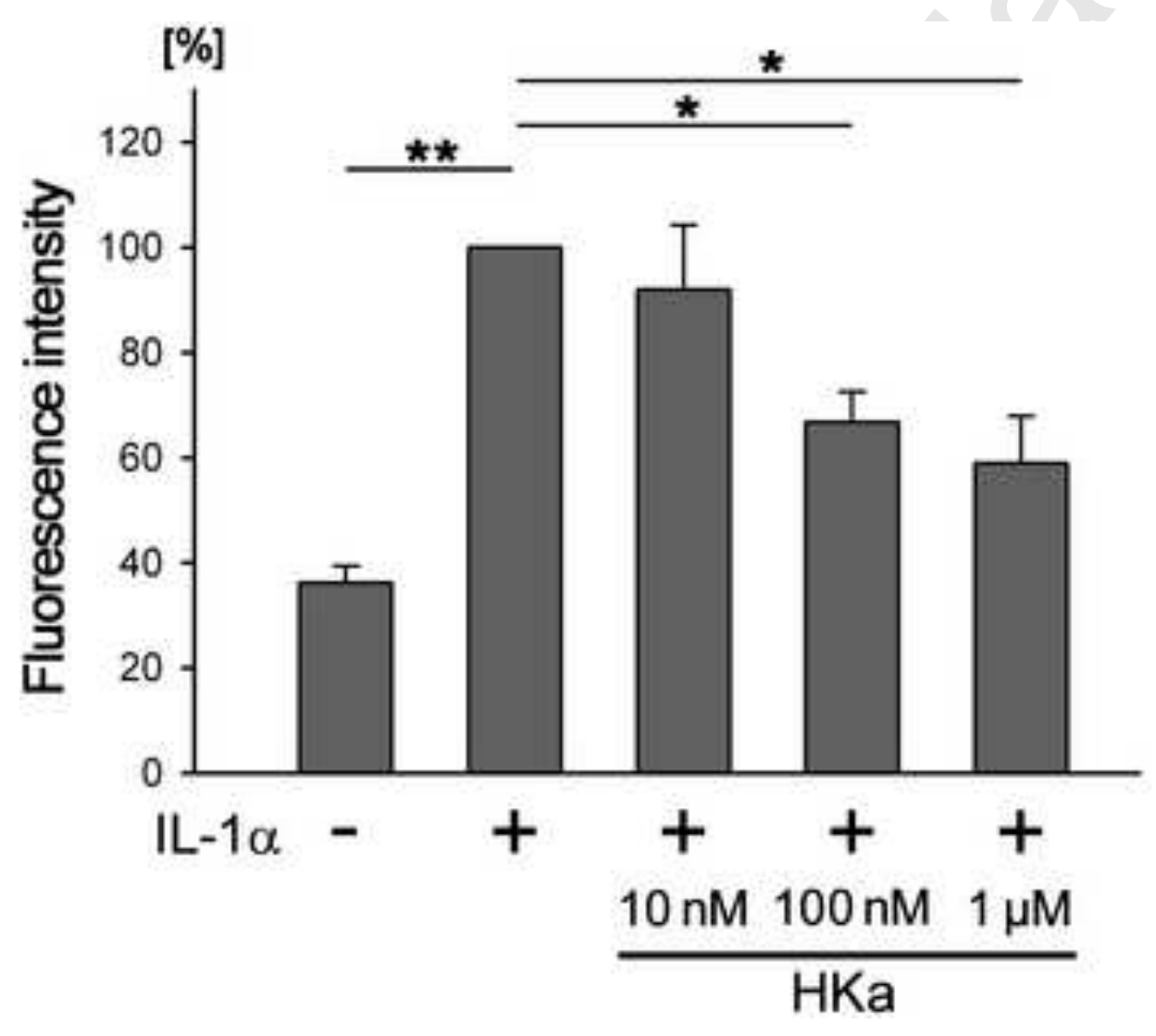



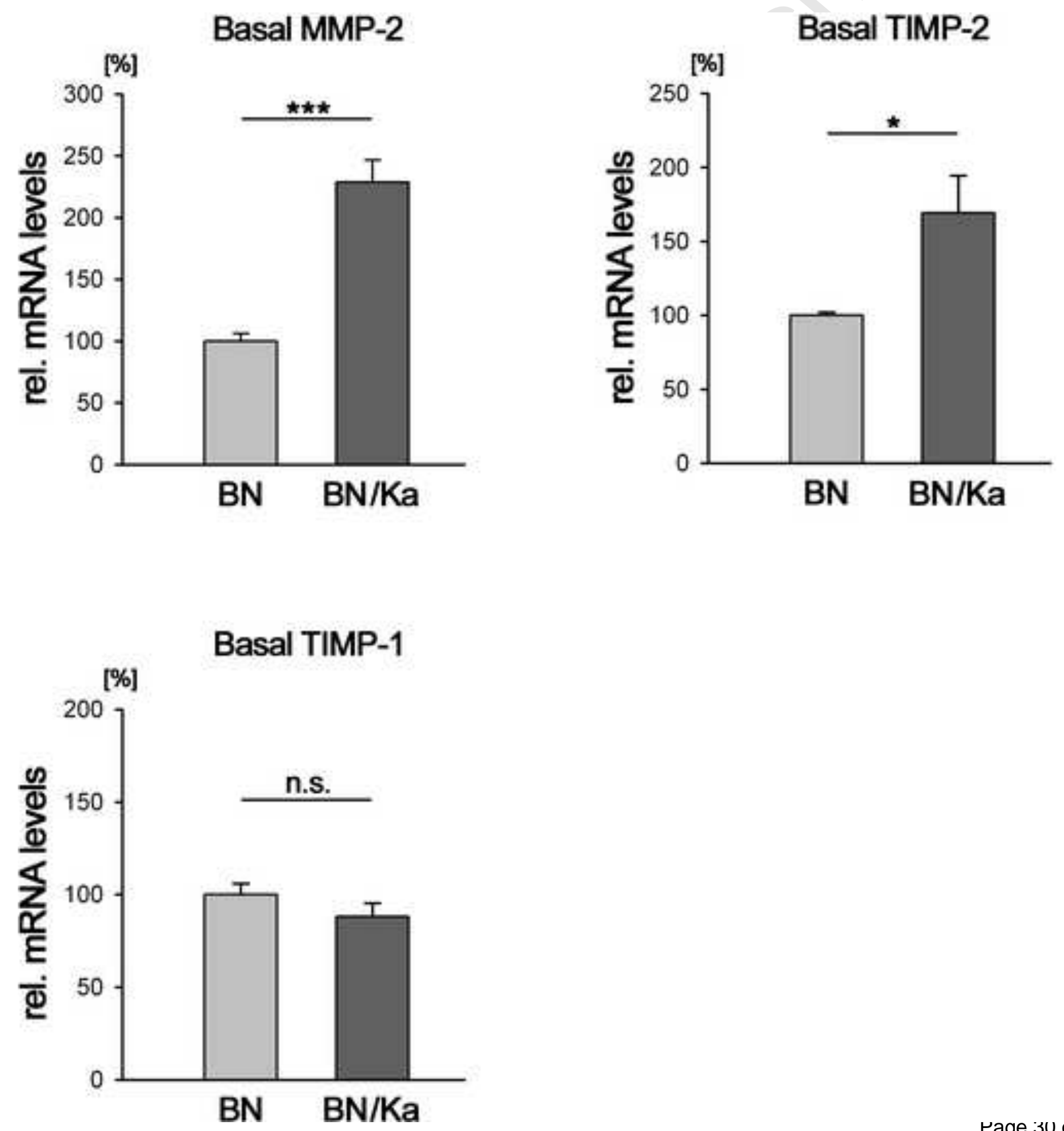
a

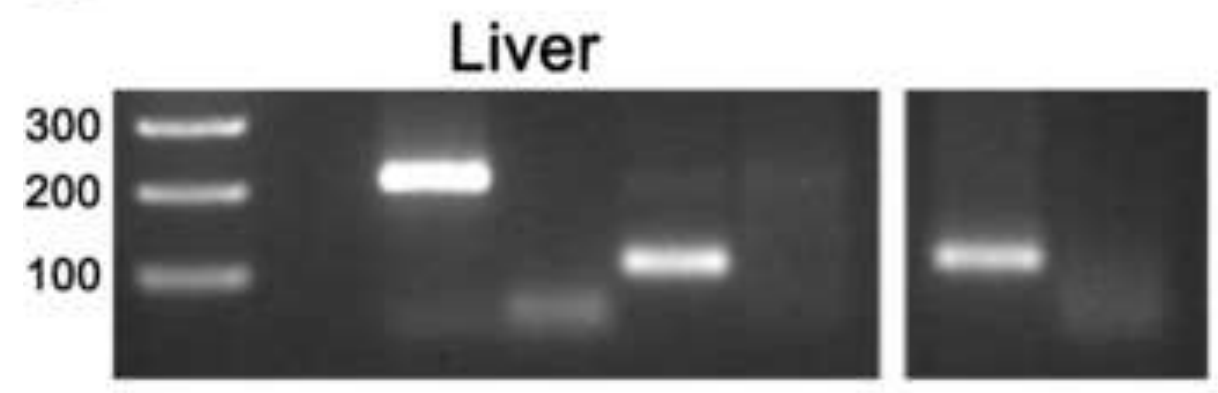

Aorta

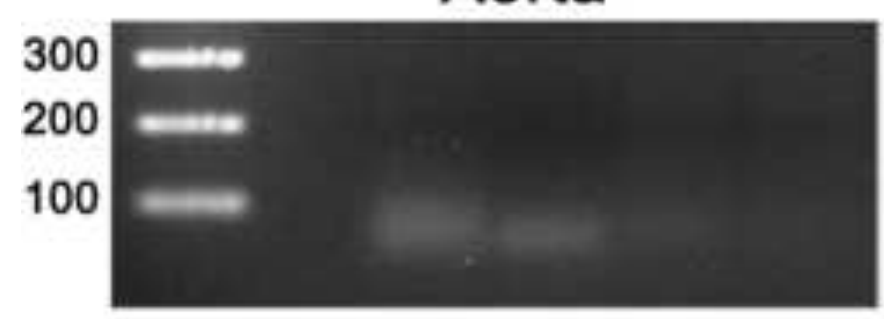

VSMC

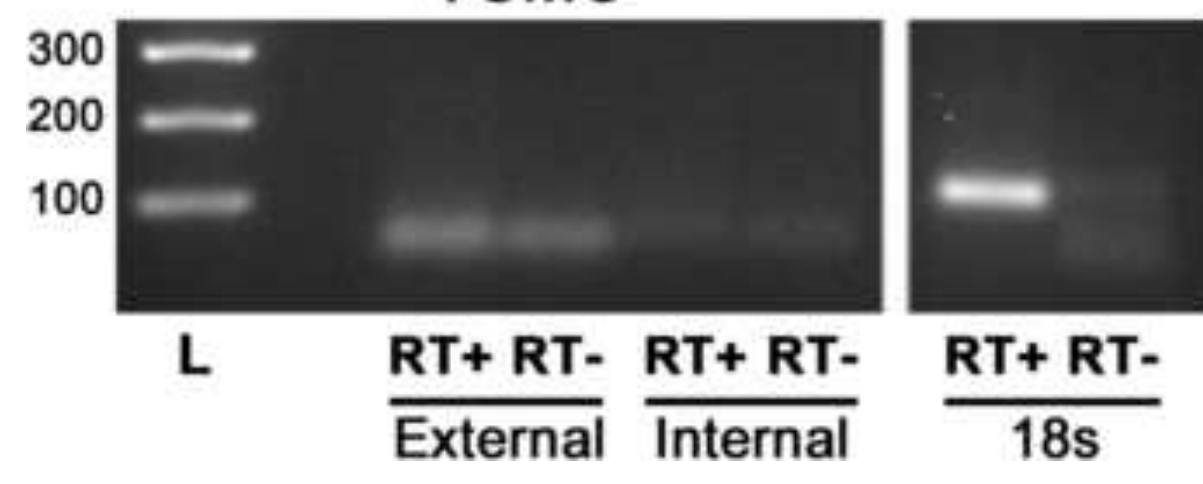

b
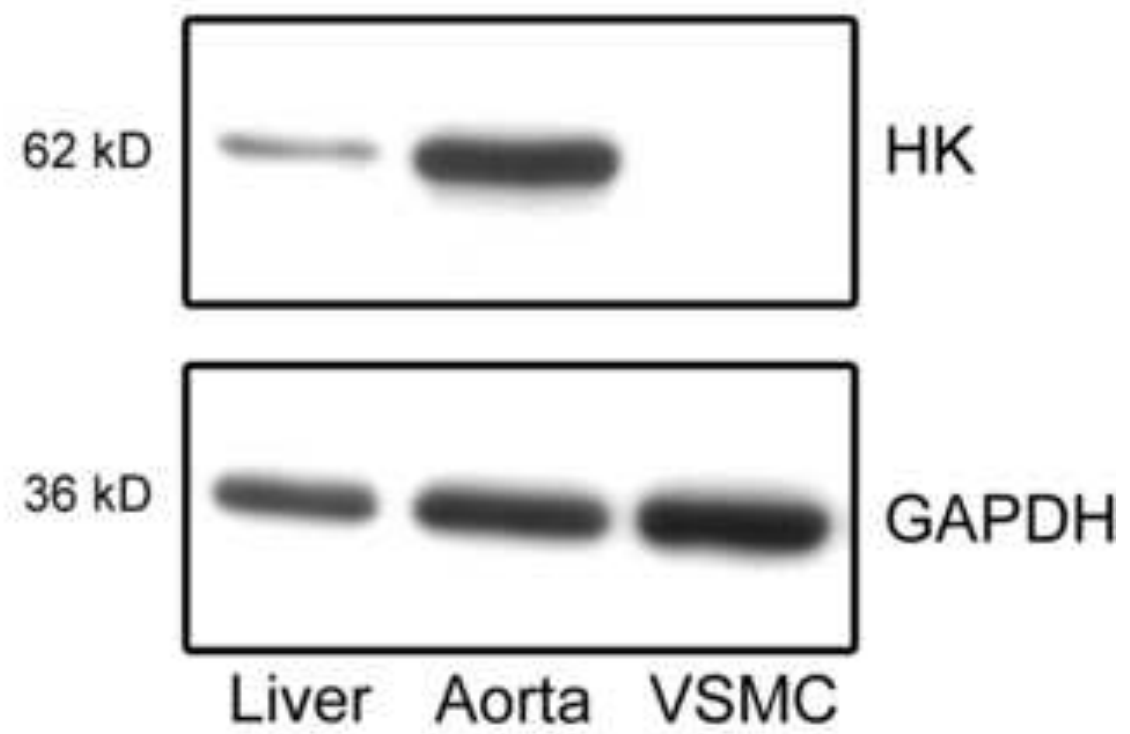